\title{
OBSERVATIONS ON CASES OF THROMBOCYTOPENIC PURPURA DUE TO QUININE, SULPHAMEZATHINE, AND QUINIDINE
}

\author{
BY \\ F. G. BOLTON* AND $R$ V. YOUNG \\ From the Department of Clinical Pathology, Radcliffe Infirmary, Oxford, and the Department of Pathology, \\ Horton General Hospital, Banbury
}

(RECEIVED FOR PUBLICATION MARCH 26, 1953)

Toxic purpura occurring in persons who have previously been sensitized by drug-taking often manifests itself with great rapidity in a matter of a few hours. Thrombocytopenia which may accompany this type of purpura can also occur in a very short time. If the natural life-span of platelets is about five days (Lawrence and Valentine, 1947 ; Hirsch and Gardner, 1952) then this rapid onset of thrombocytopenia seems to indicate a peripheral destruction of platelets rather than a central failure of production. Experiments by Ackroyd (Ackroyd, 1949a, b, and c, 1951) on the blood of patients recovering from "sedormid" purpura demonstrated in vitro the probable mechanism of platelet destruction in this condition. He has shown that "sedormid " added to blood from his patients in concentrations such as might be attained in vivo caused agglutination, and, in the presence of complement, lysis of the platelets. He found that a plasma factor was necessary for this action, and that in the presence of complement and "sedormid" plasma from his patient would cause agglutination and lysis of normal platelets.

We have carried out similar investigations on three cases of thrombocytopenic purpura which appeared to be related aetiologically to sensitization by quinine, sulphamezathine, and quinidine.

\section{Case Reports}

Case 1.-A healthy married woman of 19 years had been in the habit of taking quinine sulphate tablets at irregular intervals. At 5 p.m. on November 17 . 1951 , she took a $5 \mathrm{gr}$. $(0.32 \mathrm{~g}$. $)$ tablet of quinine sulphate. One hour later she developed tinnitus and then fainted. She found on recovery that petechial spots had appeared on her limbs, and that she was bleeding from the throat and gums. On admission

*This work was done during a period of study leave from the Department of Pathology, Royal Infirmary, Bristol. to hospital that night, she was found to have a widespread purpuric rash, several subcutaneous haematomata, and a palpable spleen. Platelets were present in very small numbers in the blood film on November 18, and on November 19 they numbered less than 10,000 per c.mm. A tourniquet test was positive, and the bleeding time by Ivy's method was more than 17 minutes. A bone-marrow film on November 20 demonstrated the presence of megakaryocytes in at least normal numbers, many of which showed an unusually marked degree of nuclear segmentation.

The patient recovered rapidly. Her platelet count rose to 207,000 per c.mm. on November 28 , and she was discharged from hospital. That afternoon she took two more quinine tablets and was readmitted to hospital the same evening with a recurrence of the bleeding diathesis from which she again rapidly recovered.

Case 2. - The patient was a male boot repairer of 50 years who in 1947 had had a course of sulphathiazole for a varicose ulcer, and in 1949 a course of sulphamezathine for right lobar pneumonia. On November 5, 1951, he was given 2 g. of sulphamezathine, followed by $1 \mathrm{~g}$. four-hourly, because he had an attack of pleurisy. On November 6, after he had been given $7 \mathrm{~g}$. of the drug, he was noticed to have a purpuric rash. and was admitted to hospital the following day. On admission he had extensive purpura, a haemorrhage into the left orbit, and large ecchymoses in the mouth and soft palate. The bleeding time on November 8 was more than 30 minutes (Ivy), and the platelet count 33,000 per c.mm. He had haematuria until November 19, and severe melaena until December 3, necessitating blood transfusions to the extent of 12 pints (6.8 litres) until, on December 3 , the platelet count, from being persistently very low, rose to 118,000 per c.mm. and his recovery began. The subsequent convalescence was uneventful.

Case 3.-A housewife of 63 years had chronic glaucoma, and was also subject to attacks of palpitations for which she took an occasional tablet of quinidine sulphate. From time to time she took 
phenobarbitone to encourage sleep. On November 9, 1951, she attended a medical out-patient department saying that 10 days previously she had developed pain in the left shoulder, and noticed the appearance of purpuric haemorrhages on the arms and legs. On examination she had purpura on the legs and hard palate. The bleeding time was 12 minutes (Ivy), the tourniquet test was positive, and the platelet count 31,000 per c.mm. A week later the platelet count was 211,000 per c.mm. and there were no further symptoms. On subsequent attendances she was found to be well. When questioned about her drug-taking, her memory was not good, but she believed that she had last taken quinidine a week before purpura appeared.

\section{Investigations and Results}

Platelet Counts.-In Cases 1 and 3 platelet counts were done on the supernatant plasma of heparinized venous blood taken into a silicone-coated glass tube, the red cells being allowed to sediment. A white-cell diluting pipette was used, $3.8 \%$ sodium citrate being taken to the mark 0.5 , plasma to the mark 1 , and the pipette then being filled with $3.8 \%$ sodium citrate. It was shaken for five minutes in a mechanical shaker, and a Neubauer counting chamber was filled. The platelets were allowed to settle, and the number in 80 small squares was counted.

In Case 2 heparinized venous blood was taken into a waxed glass tube. The red cells were allowed to sediment, and the count was done by Lempert's modification of Kristensen's method (Lempert, 1935), the pipette being shaken by hand for five minutes and a Neubauer chamber used as before.

Effect of Adding to Whole Blood Small Quantities of the Suspected Drugs.-For Case $10.05 \mathrm{ml}$. of $0.14 \%$ quinine hydrochloride in saline was mixed in a silicone-coated tube at room temperature with $5.05 \mathrm{ml}$. of heparinized venous blood taken from the patient when in remission. Stained films made from the mixture demonstrated that the platelets were markedly agglutinated at 30 minutes and that platelet lysis began at 50 minutes from mixing the blood with quinine. The changes increased in the next four hours with the result that ultimately platelet clusters were few and quite amorphous in appearance. Platelet agglutination was also to be seen in the counting chamber. Details of the platelet counts are given in Table I.

For Case $20.1 \mathrm{ml}$. of a $2 \mathrm{~g}$ \% solution of sodium sulphamezathine in serum was added to $10 \mathrm{ml}$. of
TABLE I

EFFECT OF QUININE ON PLASMA PLATELET COUNT OF CASE 1

\begin{tabular}{|c|c|c|c|c|c|c|c|}
\hline \multirow{2}{*}{ 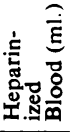 } & \multirow{2}{*}{ 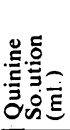 } & \multirow{2}{*}{ 总宝 } & \multicolumn{4}{|c|}{ Plasma Platelet Count After } & \multirow[b]{2}{*}{$\stackrel{5}{\text { Hours }}$} \\
\hline & & & $\begin{array}{c}1 \\
\text { Hour }\end{array}$ & $\stackrel{2}{\text { Hours }}$ & $\stackrel{3}{\text { Hours }}$ & $\stackrel{4}{\text { Hours }}$ & \\
\hline $\begin{array}{l}5.05 \\
5.05\end{array}$ & $\begin{array}{l}0 \cdot 05 \\
0\end{array}$ & $\begin{array}{l}0 \\
0.05\end{array}$ & $\begin{array}{r}86,000 \\
410,000\end{array}$ & $\begin{array}{r}49,000 \\
482,000\end{array}$ & $\begin{array}{r}38,000 \\
436,000\end{array}$ & $\begin{array}{r}41,000 \\
433,000\end{array}$ & $\begin{array}{r}43,000 \\
422,000\end{array}$ \\
\hline
\end{tabular}

venous blood in a waxed glass tube at room temperature. Blood was taken from the patient when in remission. Stained films showed that platelet agglutination occurred to a marked extent after 30 minutes, and lysis began after 45 minutes. The platelet count on the supernatant plasma fell steeply in one hour (Table II).

TABLE II

EFFECT OF SULPHAMEZATHINE ON PLASMA PLATELET COUNT OF CASE 2

\begin{tabular}{c|c|c|c}
\hline $\begin{array}{c}\text { Heparinized } \\
\text { Blood } \\
(\mathrm{ml} .)\end{array}$ & $\begin{array}{c}\text { Sulphamezathine } \\
\text { Solution } \\
(\mathrm{ml})\end{array}$ & \multicolumn{2}{|c}{ Plasma Platelet Count } \\
\cline { 2 - 4 } $10 \cdot 1$ & 0 & Initial & After 1 Hour \\
\hline $10 \cdot 1$ & $0 \cdot 1$ & 209,000 & 162,000 \\
278,000 & 9,000
\end{tabular}

For Case $30.05 \mathrm{ml}$. of a saturated solution of quinidine sulphate in saline was mixed in a siliconecoated tube at room temperature with $5.05 \mathrm{ml}$. of heparinized blood from the patient when in remission. Well-marked platelet agglutination occurred within one hour, but in this case no platelet lysis was observed. The platelet count on the supernatant plasma revealed a slow progressive fall in platelet concentration over several hours (Table III). This was not the result of platelet lysis as far as could be determined by the stained film, but was probably due to sedimentation of the platelet masses. Simultaneous experiments with phenobarbitone and quinine failed to demonstrate platelet agglutination, suggesting that the patient had not acquired sensitivity to phenobarbitone, and that there was no cross-sensitivity to quinine, the stereoisomer of quinidine.

Control experiments using normal blood samples and the same solutions of quinine, quinidine, sulphamezathine, and phenobarbitone failed to cause platelet loss, agglutination, or lysis in the supernatant plasma (Tables IVa and IVb). The control experiments were carried out within two or three days of the test experi-

TABLE III

EFFECT OF QUINIDINE, QUININE, AND PHENOBARBITONE ON PLASMA PLATELET COUNT OF CASE 3

\begin{tabular}{|c|c|c|c|c|c|c|c|c|c|c|}
\hline \multirow{2}{*}{$\begin{array}{l}\text { Heparin- } \\
\text { ized } \\
\text { Blood } \\
\text { (ml.) }\end{array}$} & \multirow{2}{*}{$\begin{array}{c}\text { Quinidine } \\
\text { Solution } \\
\text { (ml.) }\end{array}$} & \multirow{2}{*}{$\begin{array}{c}\text { Quinine } \\
\text { Solution } \\
\text { (ml.) }\end{array}$} & \multirow{2}{*}{$\begin{array}{c}\text { Pheno- } \\
\text { barbitone } \\
\text { Solution } \\
\text { (ml.) }\end{array}$} & \multirow{2}{*}{$\begin{array}{l}\text { Saline } \\
\text { (ml.) }\end{array}$} & \multicolumn{6}{|c|}{ Plasma Platelet Count After } \\
\hline & & & & & $1 \mathrm{hr}$. & $2 \mathrm{hr}$. & $3 \mathrm{hr}$. & $4 \mathrm{hr}$. & $5 \mathrm{hr}$. & $6 \mathrm{hr}$. \\
\hline $\begin{array}{l}5.05 \\
5.05 \\
5.05 \\
5.05\end{array}$ & $\begin{array}{l}0 \cdot 05 \\
0 \\
0 \\
0\end{array}$ & $\begin{array}{l}0 \\
0.05 \\
0 \\
0\end{array}$ & $\begin{array}{l}0 \\
0 \\
0 \cdot 05 \\
0\end{array}$ & $\begin{array}{l}0 \\
0 \\
0 \\
0.05\end{array}$ & $\begin{array}{l}390,000 \\
553,000 \\
486,000 \\
395,000\end{array}$ & $\begin{array}{l}350,000 \\
453,000 \\
476,000 \\
401,000\end{array}$ & $\begin{array}{l}281,000 \\
579,000 \\
489,000 \\
491,000\end{array}$ & $\begin{array}{l}255,000 \\
530,000 \\
429,000 \\
384,000\end{array}$ & $\begin{array}{l}222,000 \\
433,000 \\
456,000 \\
433,000\end{array}$ & $\begin{array}{l}152,000 \\
327,000 \\
400,000 \\
432,000\end{array}$ \\
\hline
\end{tabular}


TABLE IVa

EFFECT OF QUININE, QUINIDINE, AND PHENOBARBITONE ON NORMAL BLOOD

\begin{tabular}{|c|c|c|c|c|c|c|c|c|}
\hline \multirow{2}{*}{$\begin{array}{l}\text { Heparinized } \\
\text { Blood } \\
\text { (ml.) }\end{array}$} & \multirow{2}{*}{$\begin{array}{l}\text { Quinine } \\
\text { Solution } \\
\text { (ml.) }\end{array}$} & \multirow{2}{*}{$\begin{array}{l}\text { Quinidine } \\
\text { Solution } \\
\text { (ml.) }\end{array}$} & \multirow{2}{*}{$\begin{array}{c}\text { Phenobarbitone } \\
\begin{array}{c}\text { Solution } \\
\text { (ml.) }\end{array}\end{array}$} & \multirow{2}{*}{$\begin{array}{l}\text { Saline } \\
(\mathrm{ml} .)\end{array}$} & \multicolumn{4}{|c|}{ Plasma Platelet Count After } \\
\hline & & & & & $2 \mathrm{hr}$ & $3 \mathrm{hr}$. & $4 \mathrm{hr}$. & $5 \mathrm{hr}$. \\
\hline $\begin{array}{l}5 \cdot 05 \\
5 \cdot 05 \\
5 \cdot 05 \\
5 \cdot 05\end{array}$ & $\begin{array}{l}0 \\
0 \cdot 05 \\
0 \\
0\end{array}$ & $\begin{array}{l}0 \\
0 \\
0 \cdot 05 \\
0\end{array}$ & $\begin{array}{l}0 \\
0 \\
0 \\
0 \cdot 05\end{array}$ & $\begin{array}{l}0 \cdot 05 \\
0 \\
0 \\
0\end{array}$ & $\begin{array}{l}598,000 \\
640,000 \\
660,000 \\
700.000\end{array}$ & $\begin{array}{l}555,000 \\
616,000 \\
516,000 \\
736,000\end{array}$ & $\begin{array}{l}436,000 \\
524,000 \\
640.000 \\
611,000\end{array}$ & $\begin{array}{l}710,000 \\
511,000 \\
511,000 \\
544,000\end{array}$ \\
\hline
\end{tabular}

TABLE IVb

EFFECT OF SULPHAMEZATHINE ON NORMAL BLOOD

\begin{tabular}{|c|c|c|c|c|c|}
\hline \multirow{2}{*}{$\begin{array}{l}\text { Heparin- } \\
\text { ized } \\
\text { Blood } \\
(\mathrm{ml})\end{array}$} & \multirow{2}{*}{$\begin{array}{l}\text { Sulpha- } \\
\text { mezathine } \\
\text { Solution } \\
\text { (ml.) }\end{array}$} & \multirow{2}{*}{$\underset{(\mathrm{ml} .)}{\text { Normal }}$} & \multicolumn{3}{|c|}{ Plasma Platelet Count } \\
\hline & & & Initial & $\begin{array}{l}\text { After } \\
1 \mathrm{hr} \text {. }\end{array}$ & $\begin{array}{l}\text { After } \\
2 \mathrm{hr} .\end{array}$ \\
\hline $\begin{array}{l}5 \cdot 0 \\
5 \cdot 0\end{array}$ & $\begin{array}{l}0 \cdot 05 \\
0\end{array}$ & $\begin{array}{l}0 \\
0.05\end{array}$ & $\begin{array}{l}312,000 \\
321,000\end{array}$ & $\begin{array}{l}293,000 \\
287,000\end{array}$ & $\begin{array}{l}256,000 \\
281,000\end{array}$ \\
\hline
\end{tabular}

ments; the investigations were too time-consuming to enable simultaneous normal blood experiments to be done.

Further experiments were carried out on Case 3 to attempt to unravel further this phenomenon. Quinidine sulphate caused no change in morphology or in any tendency to agglutinate a saline suspension of washed normal platelets or washed platelets from the patient.

Platelet-free plasma, obtained from the heparinized blood of this patient by centrifuging at high speed, was able to cause agglutination of platelets in normal platelet-rich plasma in the presence of quinidine sulphate (Table V). No platelet lysis was detected in

TABLE $V$

THE MECHANISM OF PLATELET AGGLUTINATION OF CASE 3

\begin{tabular}{|c|c|c|c|c|c|c|}
\hline \multirow{2}{*}{$\begin{array}{c}\text { Normal } \\
\text { Platelet- } \\
\text { rich } \\
\text { Plasma } \\
\text { (ml.) }\end{array}$} & \multirow{2}{*}{$\begin{array}{c}\text { Patient's } \\
\text { Platelet- } \\
\text { free } \\
\text { Plasma } \\
\text { (ml.) }\end{array}$} & \multirow{2}{*}{$\begin{array}{l}\text { Quinidine } \\
\text { Solution } \\
(\mathrm{ml} .)\end{array}$} & \multirow{2}{*}{$\begin{array}{c}\text { Saline } \\
(\mathrm{ml} l .)\end{array}$} & \multicolumn{3}{|c|}{$\begin{array}{l}\text { Presence }(+) \text { or Absence } \\
(-) \text { of Platelet Clusters }\end{array}$} \\
\hline & & & & $\begin{array}{c}\text { After } \\
15 \mathrm{~min}\end{array}$ & $90 \mathrm{~min}$. & $180 \mathrm{~min}$. \\
\hline $\begin{array}{l}1.0 \\
1-0 \\
1-0\end{array}$ & $\begin{array}{l}0 \\
0 \cdot 5 \\
0 \cdot 5\end{array}$ & $\begin{array}{l}0 \cdot 1 \\
0 \cdot 1 \\
0\end{array}$ & $\begin{array}{l}0 \cdot 5 \\
0 \\
0 \cdot 1\end{array}$ & $\ddot{-}$ & $\begin{array}{l}- \\
+ \\
-\end{array}$ & $\underline{+}$ \\
\hline
\end{tabular}

this experiment. It was observed that, when the patient's plasma was stored frozen solid for more than two days, ${ }^{*}$ the ability to agglutinate platelets in the presence of quinidine sulphate was lost. The addition of normal fresh human serum restored this power without affecting the control tube. The nature of the serum factor was not investigated.

As quinidine sulphate is only sparingly soluble in saline it was thought that the absence of lysis in these experiments might be due to an insufficiency of quinidine in the test blood. Accordingly $0.05 \mathrm{ml}$. of $0.14 \%$ quinidine lactate in saline was used ; this, however, did not materially alter the experimental results.

\footnotetext{
* "Complement" deteriorates only slowly in frozen serum.
}

In Cases 1 and 3 saline suspensions of washed platelets were made, and anti-human globulin serum was added in an attempt to detect a possible coating antibody. There appeared to be no increase in the agglutination of these washed platelets, despite the natural tendency of these saline suspensions of platelets to agglutinate to some degree.

In none of these three patients were we able to cause local purpura, or increase in local capillary fragility by patch-testing with watery suspensions of the appropriate drug.

\section{Discussion}

It has been shown in Cases 1 and 2 that rapid in vitro agglutination and lysis of platelets followed the addition of quinine and of sulphamezathine to the blood of these patients. Case 3 was shown to possess a plasma factor which, in the presence of normal platelets, quinidine, and a serum factor, was able to cause platelet agglutination. The disease process in this patient was mild compared with Cases 1 and 2, and corresponded roughly with Ackroyd's third case in severity. Further examples of what might well be called the "Ackroyd phenomenon" have been described in two cases of quinidine purpura (Bigelow and Desforges, 1952), in one of which the plasma rather than the platelets was at fault. A case of quinine purpura (Grandjean, 1948) has been described, when it was noted that the addition of quinine to platelet-rich plasma from the patient resulted in a significant fall in the platelet count. None of the nine patients in whom this phenomenon has been demonstrated had developed purpura on first taking the offending drugs; presumably an acquired sensitivity to the drug had developed. It was not clear from the history of our third case whether phenobarbitone or quinidine was likely to be responsible for the purpura ; however, the investigations seemed to point to quinidine as the cause of the disease.

It is possible that thrombocytopenic purpura occurring as an acquired sensitivity to drugs other than "sedormid," sulphamezathine, quinine, and quinidine may be associated also with this type of platelet agglutination, and it would probably be of value in diagnosis to determine the in vitro platelet 
agglutinating potentialities of the drug in question. It is recommended that glassware be rendered water-repellent before embarking on such an investigation.

\section{Conclusions}

Three cases of toxic thrombocytopenic purpura are described due to acquired sensitivity to quinine, sulphamezathine, and quinidine.

The addition of the offending drug to plateletrich plasma from each of these three patients readily caused platelet agglutination and lysis in two, and platelet agglutination only in the third.
We should like to thank Dr. R. G. Macfarlane for his interest and advice in this work, and Dr. F. G. Hobson, Dr. P. C. Mallam, and Dr. H. R. Wynne for permission to publish details of their cases.

\section{REFERENCES}

Ackroyd, J. F. (1949a). Clin. Sci., 7, 249.

(1949b). Ibid., 8, 235.

- (1949c). Ibid., 8, 269.

(1951). Ibid., 10, 185.

Bigelow, F. S., and Desforges, J. F. (1952). Amer. J. med. Sci., 224 274.

Grandjean, L. C. (1948). Acta med. scand., Suppl. 213, p. 165.

Hirsch, E. O., and Gardner, F. H. (1952). J. Lab. clin. Med., 39, 556. Lawrence, J. S., and Valentine, W. N. (1947). Blood, $2,40$.

Lempert, H. (1935). Lancet, 1, 151. 